\title{
Three-dimensional Finite Element Simulation Analysis of Bridge-type Inverted Siphon Structure
}

\author{
Dongyu $\mathrm{Ji}^{\mathrm{a}}$ \\ Hunan Urban Construction College, Xiangtan, Hunan Province 411101, P.R. China \\ ahnjdy@126.com
}

Keywords: Lingyun inverted siphon, Simulation analysis, Finite element method, Stress distribution

\begin{abstract}
This paper adopts general finite element software to analyse Lingyun bridge-type inverted siphon structure, researching variation law of the inverted siphon's stress and displacement in construction process and operational process. Research results further verified rationality and security of the design schemes, which provides reliable reference for construction and operational of inverted siphon structure.
\end{abstract}

\section{Project summary}

Lingyun inverted siphon engineering is located main canal of Gaoling reservoir irrigation, which is located Muping county in Shandong province. The engineering adopts bridge-type inverted siphon structure form, inverted siphon is cast-in-place reinforced concrete pipe structure, concrete strength grade of inverted siphon is C25, rebar is II grade. Inverted siphon according to the different head reinforcement, juncture of inverted siphon adopts flat joint form, rubber ring sealing is adopted. Inverted siphon's flow rate is $3.7 \mathrm{~m}^{3} / \mathrm{s}$, flow velocity is $1.1 \mathrm{~m} / \mathrm{s}$, roughness is 0.014 , inner diameter of reinforced concrete pipe is $1.6 \mathrm{~m}$, wall thickness is $0.2 \mathrm{~m}$. Inverted siphon's minimum level is $14.6 \mathrm{~m}$, design level is $16.6 \mathrm{~m}$, maximum level is $18 \mathrm{~m}$, overall length is $813 \mathrm{~m}$.

\section{Structure Force Calculation}

Model Parameters. Concrete strength grade of Lingyun inverted siphon pipe is C25, elastic modulus $\mathrm{E}_{1}=28 \mathrm{GPa}^{[1]}$, Poisson ratio $\mu_{1}=0.167$, density $\gamma_{1}=24 \mathrm{kN} / \mathrm{m}^{3}$. Concrete strength grade of arch and bent is $\mathrm{C} 15$, elastic modulus $\mathrm{E}_{2}=22 \mathrm{GPa}$, Poisson ratio $\mu_{2}=0.167$, density $\gamma_{2}=24 \mathrm{kN} / \mathrm{m}^{3}$. Inverted siphon's pier adopts grouting stone-laying, elastic modulus $\mathrm{E}_{3}=18 \mathrm{GPa}^{[2]}$, Poisson ratio $\mu_{3}=0.28$, density $\gamma_{3}=28 \mathrm{kN} / \mathrm{m}^{3}$.

Element Selection and Model Size. Force analysis is proceeded for Lingyun inverted siphon, inverted siphon pipe, arch, bent and pier are divided by eight nodes isoparametric block element. The element is often applied to three-dimensional model of entity structure, it has eight nodes, each node has three translational degree of freedoms ${ }^{[3]}$. And reinforced concrete pipe adopts to overall rebar role model, it simulates rebar role through defining reinforcement ratio in all directions ${ }^{[4]}$. When inverted siphon structure calculation model is established, it simulates mainly inverted siphon horizontal segment, horizontal segment's water pressure is maximum. Calculation model size is listed below, calculation model along inverted siphon pipe is $20 \mathrm{~m}$, transverse of inverted siphon pipe is $4.6 \mathrm{~m}$, vertical direction is $15 \mathrm{~m}$. The simulation range of whole calculation model is 20 $\mathrm{m} \times 4.6 \mathrm{~m} \times 15 \mathrm{~m}$. Element division of inverted siphon structure is shown in Fig.1.

Calculation Cases. Considering mechanical characteristics of Lingyun inverted siphon structure in construction and operational process, researching four cases as follows ${ }^{[5]}$. Case 1 , inverted siphon pipe weight; case 2, inverted siphon pipe weight and minimum level $(14.6 \mathrm{~m})$; case 3 , inverted siphon pipe weight and design level $(16.6 \mathrm{~m})$; case 4 , inverted siphon pipe weight and maximum level $(18 \mathrm{~m})$. 


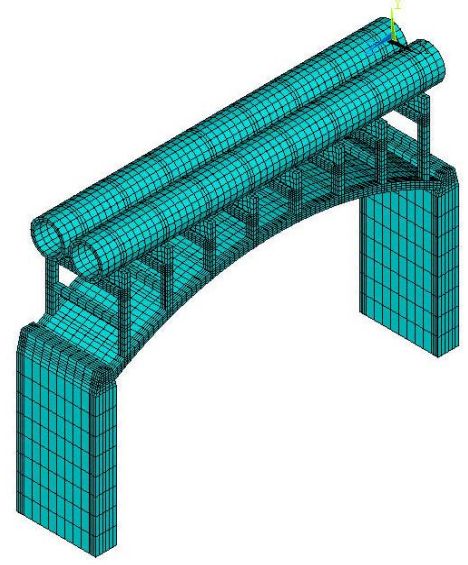

Fig.1 Element division of inverted siphon structure

\section{Calculation Results Analysis}

Paths Selection. In order to know clearly stress and deformation of inverted siphon structure, from the middle section of inverted siphon, from top of inverted siphon pipe to bottom of pipe, choosing respectively seven calculation points along with clockwise on internal and outside surface of inverted siphon pipe. Two analysis paths are confirmed, Path 1, internal surface of inverted siphon pipe, Path 2, outside surface of inverted siphon pipe. Stress and deformation distribution of these analysis paths are provided in the paper.

Stress Analysis. Under various cases, calculation points circumferential stress distribution of inverted siphon pipe's analysis paths in construction and operating process is listed in the table 1 .

Table 1. Calculation points circumferential stress value of analysis paths under various cases(MPa)

\begin{tabular}{|c|c|c|c|c|c|c|c|c|}
\hline \multicolumn{2}{|c|}{ Calculation Point } & (1) & (2) & (3) & (4) & (5) & (6) & (7) \\
\hline \multirow{2}{*}{ Case 1 } & Path 1 & -0.05 & -0.11 & -0.01 & 0.08 & 0.14 & 0.07 & -0.06 \\
\cline { 2 - 9 } & Path 2 & -0.01 & 0.05 & 0.01 & -0.04 & -0.06 & 0.01 & 0.12 \\
\hline \multirow{2}{*}{ Case 2 } & Path 1 & 0.61 & 0.50 & 0.62 & 0.75 & 0.84 & 0.79 & 0.63 \\
\cline { 2 - 9 } & Path 2 & 0.45 & 0.54 & 0.53 & 0.48 & 0.44 & 0.55 & 0.69 \\
\hline \multirow{2}{*}{ Case 3 } & Path 1 & 0.70 & 0.59 & 0.70 & 0.83 & 0.93 & 0.88 & 0.73 \\
\cline { 2 - 9 } & Path 2 & 0.51 & 0.61 & 0.60 & 0.55 & 0.52 & 0.62 & 0.76 \\
\hline \multirow{2}{*}{ Case 4 } & Path 1 & 0.77 & 0.66 & 0.76 & 0.89 & 0.99 & 0.95 & 0.79 \\
\cline { 2 - 9 } & Path 2 & 0.56 & 0.65 & 0.65 & 0.60 & 0.57 & 0.67 & 0.80 \\
\hline
\end{tabular}

We can see from table 1, under inverted siphon pipe weight, circumferential stress values of inverted siphon pipe is very small, compressive stress appears in inverted siphon pipe's top, and tensile stress of inverted siphon pipe's bottom is smaller. Under internal water pressure, circumferential stress values of path 1 is greater than circumferential stress values of path 2 , this is mainly because circumferential stress of inverted siphon pipe's inside surface is greater than outside surface. On the same calculation path, from top of inverted siphon pipe to bottom of pipe, first circumferential stress values of inverted siphon pipe increase, and then circumferential stress values decrease. This is mainly because inverted siphon weight and water pressure effect together, so producing such stress distribution law.

We obtain inverted siphon structure's cloud maps of first and third principal stress under case 3, cloud maps are shown from Fig.2 to Fig.3. Inverted siphon pipe and support's middle section's contour maps of first and third principal stress under case 3 are shown from Fig. 4 to Fig.5. 


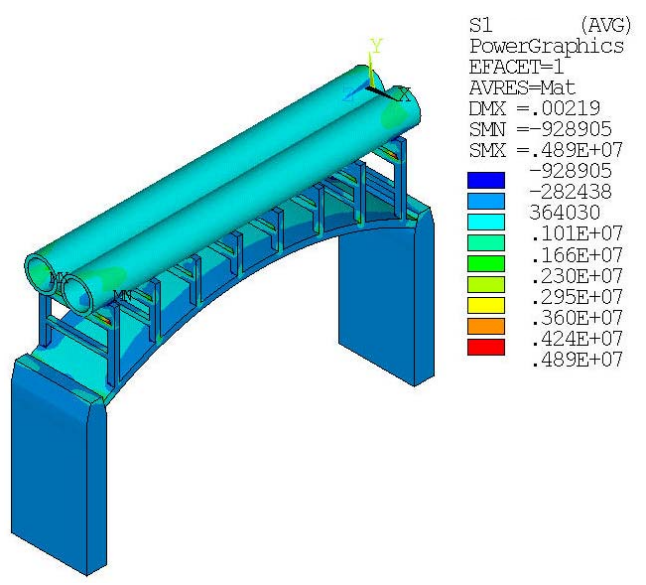

Fig.2. Inverted siphon structure's cloud map of first principal stress under case $3(\mathrm{~Pa})$

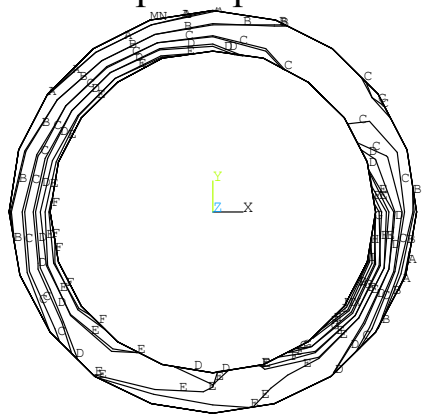

Fig.4. Inverted siphon pipe's contour map of first principal stress under case $3(\mathrm{~Pa})$

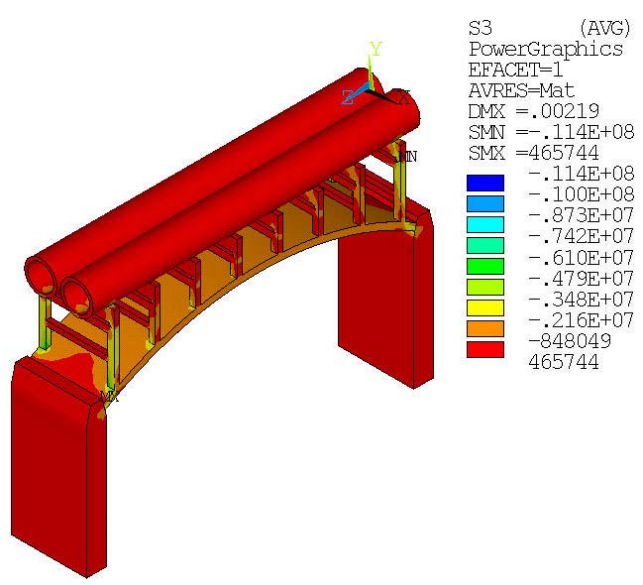

Fig.3. Inverted siphon structure's cloud map of third principal stress under case $3(\mathrm{~Pa})$

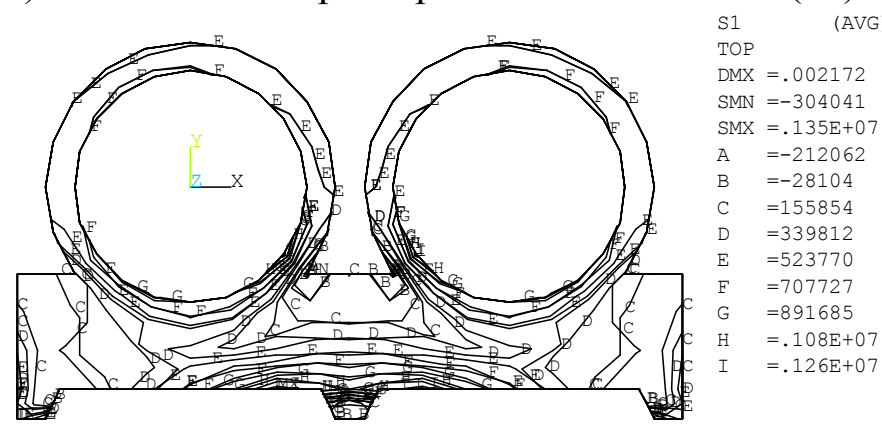

Fig.5. Inverted siphon support's contour map of first principal stress under case $3(\mathrm{~Pa})$

We can see from Fig.2 to Fig.3, inverted siphon structure's maximum first principal stress is 4.89 $\mathrm{MPa}$, it is located junction of inverted siphon support and bent. inverted siphon structure's maximum third principal stress is $-11.4 \mathrm{MPa}$, it is located junction of arch and pier. In Fig.4, maximum first principal stress inverted siphon pipe's middle section is $0.95 \mathrm{MPa}$, it is located inside surface of inverted siphon pipe's bottom, this is mainly because inverted siphon pipe weight and internal water pressure produces result. In Fig.5, maximum first principal stress inverted siphon support's middle section is $1.26 \mathrm{MPa}$, it is located inside surface of inverted siphon support's middle section, there appears certain stress concentration phenomenon.

Displacement Analysis. We obtain inverted siphon pipe's calculation points radial displacement values of path 1 under various cases in construction and operating process, radial displacement values are listed in the table 2.

Table 2. Calculation points radial displacement of path 1 under various cases $(\mathrm{mm})$

\begin{tabular}{|c|c|c|c|c|c|c|c|}
\hline Calculation Point & (1) & (2) & (3) & (4) & (5) & 6) & (7) \\
\hline Case 1 & -1.48 & -1.14 & -0.36 & 0.10 & 0.55 & 1.26 & 1.50 \\
\hline Case 2 & -2.02 & -1.54 & -0.47 & 0.16 & 0.78 & 1.75 & 2.07 \\
\hline Case 3 & -2.01 & -1.53 & -0.47 & 0.16 & 0.78 & 1.75 & 2.07 \\
\hline Case 4 & -2.01 & -1.53 & -0.46 & 0.16 & 0.78 & 1.75 & 2.06 \\
\hline
\end{tabular}

We can see from table 2, inverted siphon pipe's radial displacement values are very small under various cases, under inverted siphon pipe weight, inverted siphon pipe's radial displacement is negative, this shows that inverted siphon pipe's top appears settlement displacement. Under internal water pressure, displacement of inverted siphon pipe's waist is very small, this shows that inverted siphon pipe happens vertical rigid displacement, but radial displacement of inverted siphon pipe is very small.

Through analysing displacement of Lingyun inverted siphon, we obtain inverted siphon pipe's middle section's contour maps of total displacement under case 1 and 3, contour maps are shown 
from Fig. 6 to Fig. 7.

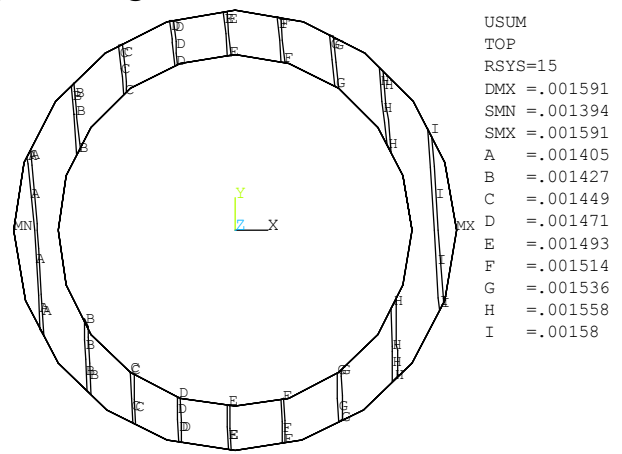

Fig.6. Inverted siphon pipe's contour map of total displacement under case $1(\mathrm{~m})$

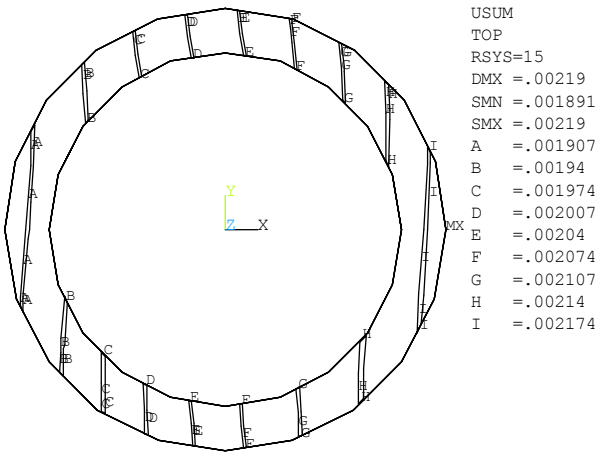

Fig.7. Inverted siphon pipe's contour map of total displacement under case $3(\mathrm{~m})$

We can see from Fig.6, inverted siphon pipe's maximum displacement is located inverted siphon pipe's waist, this is mainly because inverted siphon pipe produces overall settlement displacement under inverted siphon pipe weight. Displacement of inverted siphon pipe's waist is maximum, maximum displacement is $1.58 \mathrm{~mm}$. In Fig.7, because the influence of inverted siphon weight and internal water pressure, maximum displacement of inverted siphon pipe is $2.17 \mathrm{~mm}$, it is located inverted siphon pipe's waist.

\section{Conclusion}

Analysis results show that, stress value of Lingyun inverted siphon structure is smaller, the inverted siphon can meet strength requirements through the reinforcement. Displacement of inverted siphon is very small, it can meet rigidity requirements. So Lingyun inverted siphon structure is economic and reasonable, structure is safe and reliable.

\section{References}

[1] SL191-2008: Design Code for Hydraulic Concrete Structures(China Water Conservancy and Hydropower Press, China 2008)(in Chinese)

[2] M.R. Shen, J.F. Chen: Rock Mechanics(Tongji University Press, China 2006)(in Chinese)

[3] X.CH. Wang, M. SH: Finite Element Method Basic Principle and Numerical Method(Tsinghua University Press, China 1997)(in Chinese)

[4] J.J. Jiang, X.ZH. Lu, L.P. Ye: Finite Element Analysis of Concrete Structures(Tsinghua University Press, China 2005)(in Chinese)

[5] H.Y. Li, W.D. Tian, H.X. Yan: Inverted Siphons(China Water Conservancy and Hydropower Press, China 2006)(in Chinese) 